Issue no. $27 / 2018$

\title{
CHALLENGES FOR THE DEVELOPMENT OF SOCIAL ENTREPRENEURSHIP IN ROMANIA
}

\author{
Assoc. Prof. Dr. Nicoleta Dorina Racolța Paina \\ Faculty of European Studies, Babeș-Bolyai University Cluj Napoca \\ nicoleta.paina@ubbcluj.ro
}

\section{DOI:10.24193/OJMNE.2018.27.08}

\begin{abstract}
Social entrepreneurship is a complex phenomenon with various meanings and approaches, its main features being to create social value through social innovation, to satisfy diverse social needs at systemic level, from poverty to unemployment, from social exclusion to population aging, and so on. Social entrepreneurship activities are influenced by environmental factors that are part of the so-called entrepreneurial ecosystems, and consist of components whose interdependence and interaction have a major impact on this sector. The purpose of this exploratory research (the sources used are secondary, which leads to a desk research) is to analyze the challenges faced by social entrepreneurship in Romania from an evolutionary perspective. The analysis focuses on the legislative framework and some of the components of the ecosystem of social entrepreneurship.
\end{abstract}

Keywords: social entrepreneurship, environmental factors, Romania.

\section{Introduction}

The complex dimension of social entrepreneurial (SE) activities results from the two major meanings associated with the concept, a broad one that takes into account "individuals who are starting or currently leading any kind of activity, organization or initiative that has a particularly social, environmental or community objective", and a narrow one, with two clear indications/ restrictions stating "that this activity, organization or initiative (i) prioritizes social and environmental value over financial value; and (ii) operates in the market by producing goods and services" (Bosma, Schøtt, Terjesen, \& Kew, 2016, p. 5). SE is the result of the decisions and actions of social entrepreneurs, namely those who initiate or lead different forms of manifestation of social entrepreneurship. Their main mission is to create social value by providing solutions to the social problems concerned without, however, denying or diminishing the economic value, the 
Issue no. $27 / 2018$

latter being crucial for the sustainability of the organizational entity in question, respectively for the creation of social value (Dacin, Dacin, \& Tracey, 2011, pp. 1204, 1025). The entrepreneur's central role (his/her individual qualities, motivation, knowledge, etc.) is complemented by the process followed to become an entrepreneur, which is strongly conditioned by formal and informal institutions (Veciana \& Urbano, 2008).

In Romania, the social economy sector is experiencing a steady growth if we compare the figures for the period 2014-2015 (European Economic and Social Committee, 2017) with those from the Social Economy Atlas published in 2014, but with 2012 being the reference year (Barna, 2014), to which we add information from various studies published by organizations and foundations supporting this sector (Damaschin Țecu, 2010; Ashoka Romania, 2018). Regarding the main actors of social entrepreneurship, the current situation has not much changed since 2014, when the non-profit sector was the main actor in this area (Mateescu, 2014, p. 56). The adoption of the Law on Social Economy (Parlamentul României, 2015) is an important step in the development of social entrepreneurship in our country, the lack of a clear legal and regulatory framework being an important challenge mentioned by most stakeholders in the sector (Damaschin-T,ecu \& Etchart, 2016, p. 9). Moreover, there is an increasing commitment of the private sector towards SE, as important private entities are financing the social economy and social enterprises (Damaschin-Țecu \& Etchart, 2016, p. 13).

\section{Main research objectives}

The present study is exploratory and consists of desk research, the secondary sources originating from academic literature, the official EU documents, reports and studies published by civil society, interviews with social entrepreneurs (already published), legislation, and sites of the entities that are involved in social entrepreneurship. The purpose of this study is to analyze the challenges faced by social entrepreneurship, given the environmental factors and the components of the social economy ecosystem. Entrepreneurs, and implicitly social entrepreneurs, act in a context determined by institutions which "consist of the formal and informal rules of the games" (Boettke \& Coyne, 2009, p. 135). The approach of Douglas North (1990) is recognized to be used to study macroeconomic issues (Richter, 2005, p. 171), our interest being to study social entrepreneurship by taking into account environmental factors, considering the challenges they 
have to deal with, looking from this general framework. The use of the institutional approach in the entrepreneurship analysis has experienced a serious momentum, if we relate to the studies published over the past ten years. In the $4^{\text {th }}$ Volume Editorial from 2008 of the International Entrepreneurship and Management Journal, which was dedicated to this topic, it was appreciated that "entrepreneurship research based on institutional theory is a promising field of research" (Veciana \& Urbano, 2008, pp. 365, 373). According to this approach the autonomous actor dimension of the entrepreneur entering into a series of transactions, that constitute entrepreneurship, is complemented by the process of becoming an entrepreneur, which is highly conditioned by formal and informal institutions. We identify here the two major dimensions of entrepreneurship, on one hand the mindset dimension (also comprising capacity) and on the other hand the action (or process) dimension, both being essential to its success in the market (RacolțaPaina, 2016, pp. 44-45).

The assessment made in 2008 has come true, with many studies being published in the following years (Meek, Pacheco, \& York, 2010; Tolbert, David, \& Sine, 2010; Stenholm, Acs, \& Wuebker, 2013; Bylund \& McCaffrey, 2017; Gümüsay, 2018). Researchers interested in the field of social entrepreneurship have the opportunity to examine the assumptions and valuable results of entrepreneurial theories, in general to apply them in the context of their field of interest (Dacin, Dacin, \& Matear, 2010, p. 37). As a result, the institutional approach has also been applied in the field of social entrepreneurship (Urbano, Toledano, \& Soriano, 2010; Ferri \& Urbano, 2010; Díaz Casero, Almodóvar González, Sánchez Escobedo, Coduras Martínez, \& Hernández Mogollón, 2013; Dorado \& Ventresca, 2013). All of the above are solid arguments for building our present study.

\section{Social entrepreneurship - content, actors and environmental factors}

SE, defined as a phenomenon (Silva \& Poza, 2016), an economic process (Douglas, 2010) or a set of contextual and contingent activities, is the subject of various interpretative analyzes and measurements (Huybrechts \& Nicholls, 2012, p. 31), hence the numerous existing definitions and approaches. As a result, the confusion related to the meaning of SE and its forms in different countries (Witkamp, Royakkers, \& Raven, 2011) still persists. SE, also called the "entrepreneurial activity with an embedded social purpose" (Austin, Stevenson, \& Wei-Skillern, 
Issue no. 27/2018

2006 , p. 1), plays an important role, regardless of whether we refer to the Social Enterprise School, according to which SE aims to generate income to serve a social purpose, or to the Social Innovation School, in which case SE aims to establish new and effective ways to address social issues or meet social needs (Dees \& Battle Anderson, 2006, p. 41).

$\mathrm{SE}$ is the outcome of the social entrepreneur's action who assumes a social mission as a result of identifying a social problem "and addresses it by means of social innovation and in terms of creating social impact and social value by benefiting both the business (sustainability) and society (scalability)" (Hadad \& Găucă (Drumea), 2014, p. 119). The social value created by social entrepreneurship is "a positive output of solving social needs" (Bibu, Lisetchi, \& Nastase, 2016, p. 247), the emergence of this phenomenon being explained from different perspectives, for example "the failure thesis/institutional void perspective, the interdependence theory/institutional support perspective, welfare state theory, and supply-side theory" (Hoogendoorn, 2016, p. 279). SE and its associated activities seek solutions to various structural problems (such as poverty, unemployment and social exclusion), problems that "go hand in hand" (Reianu, 2015, p. 14). Therefore, solutions are coming rather from civil society than the government or the business sector (Zoehrer, 2017, p. 8). The social entrepreneur is "a missiondriven individual who uses a set of entrepreneurial behaviours to deliver a social value to the less privileged, all through an entrepreneurially oriented entity that is financially independent, selfsufficient, or sustainable" (Abu-Saifan, 2012, p. 25). The social entrepreneur establishes and develops entities, the so-called social entrepreneurship organizations (SEOs), which aim at creating social value by using business principles, reflected in a new framework (Schmidt \& Carsten, 2014). SEOs are found both in the non-profit sector (in the case of non-governmental organizations that create social value and are self-sustaining) and in the for-profit sector, the latter having a social purpose, simultaneously carrying out social and commercial entrepreneurial activities to be sustainable (Abu-Saifan, 2012). From a statistical perspective, given their number and social impact, the broadest category of SEOs consists of non-profit non-governmental organizations (usually called NGOs), including both organizations and foundations (Bibu et al, 2012 quoted by Bibu, Lisetchi, \& Nastase, 2016, p. 246). In turn, they are a part of the so-called "third sector" or "non-profit sector", which in the Central and Eastern European countries embeds all types of civil society activities with a permanent or formal structure, "including 
Issue no. $27 / 2018$

cooperatives and mutual that allow profit distribution" (Salamon \& Sokolowski, 2014, p. 14). Thus, non-profit non-governmental organizations as forms of SEOs are complemented by entities operating in the social economy sector, an important category being represented by social enterprises. In fact, social enterprises are seen "as an important business model that can support economic growth and social progress" (ESELA- European Social Enterprise Law Association, 2015).

The development of entrepreneurship, and implicitly of social enterprises, involves the existence of entrepreneurship ecosystems consisting of several individual elements that combine in a complex way, the general areas being culture, politics and leadership, finance, human capital, markets, support (Isenberg, 2010, p. 41). Therefore, "the environment and 'ecosystem' of the social economy is a major factor that can facilitate the development of social economy entities or can constitute an external barrier to them" (European Economic and Social Committee, 2017, p. 7). Entrepreneurial ecosystems (EE) are "combinations of social, political, economic, and cultural elements within a region that support the development and growth of innovative startups and encourage nascent entrepreneurs and other actors to take the risks of starting, funding, and otherwise assisting high-risk ventures" (Spiegel, 2015, p. 50). From the perspective of the authors in the fields of entrepreneurship and organizational theories, the interest in EE addresses issues such as the availability of financial capital for funding; the existence of support entities - such as business incubators and accelerators, the existence of certain workforce characteristics and cultures in which the risk assumption and innovation are encouraged, and failure is accepted (Roundy, 2017, p. 4).

In the context of SE being perceived as a "process resulting from the continuous interaction between social entrepreneurs and the context in which they and their activities are embedded" (Mair \& Martí, 2006, p. 40) it is necessary to resort to institutional theory, knowing that "institutions matter, the relationship between institutional structure and economic behavior requires attention, the determinants of institutions can be analyzed with the aid of economic theory" (Richter, 2005, p. 161). North's approach (1990), according to which institutions are "formal and informal rules governing human behaviour" (North, 1990, 1991 cited in Boettke \& Coyne, 2009) is the one used by the authors studying the institutional approach of SE. Thus, Veciana and Urbano consider six large categories of environmental factors that influence social 
Issue no. $27 / 2018$

entrepreneurship activities, namely public spending, access to finance and governance effectiveness (formal institutions), respectively social needs, societal attitudes and education (informal institutions) (Veciana \& Urbano, 2008, p. 9). By formal institutions, Urbano et al. (2010) refer to support mechanisms for promoting social enterprises, their existence facilitating the implementation of SE, and by informal institutions they refer to social networks used to attract human resources, rather than financial resources, the latter being provided by formal institutions (Urbano, Toledano, \& Soriano, 2010, p. 65). In terms of attracting financial resources, the SME sector has to cope with major financial constraints (Racolța-Paina \& BurcăVoicu, 2013, p. 31).

The social entrepreneurship education model consists of two parts, namely one in which students are taught "about" entrepreneurship and SE (focusing on identifying opportunities, social opportunities, types of social businesses, etc.), respectively the second, where the students are coached for these activities, and they are taught entrepreneurship and SE (aimed at developing entrepreneurial skills, more precisely those who "bridge competing social-welfare, commercial and public-sector logics") (Pache \& Chowdhury, 2012, p. 500). As "entrepreneurship education has to start in the primary schools .., ..., entrepreneurship is above all a mindset." (Duma, 2014, p. 71), we believe that, at this level, the first steps towards SE education can be made. At European Union level, social entrepreneurship is approached together with social economy, given the multitude of definitions and meanings of these concepts, both in the literature and at the level of public discourse (European Commission, Directorate-General for Employment, Social Affairs and Inclusion, 2013, p. 7). Social economy, as an activity, is linked to four major categories of organizations, namely cooperatives, mutual societies, associations and foundations, whose historical roots are given by "the response of the most vulnerable and defense less social groups, through self-help organisations, to the new living conditions created by the development of industrial society in the 18th and 19th centuries" (CIRIEC, Centre of Research and Information on the Public, 2012, p. 14). The development of the social economy sector takes place in the "space left" by the governmental and market sectors, given that there are social needs that are not enough or adequately solved by the private capitalist or public sectors, respectively "for which no easy solution is to be found through self-adjusting markets or traditional macroeconomic policy" (CIRIEC, Centre of Research and Information on the Public, 2012, p. 
Issue no. $27 / 2018$

17). Promoting social enterprises addressing certain groups facing obstacles to entering the labor market (such as people with disabilities, those with mental health problems, former convicts, people from marginalized communities, etc.) is one of the priorities of the Promoting Social Inclusion domain, which is one of the four domains targeted by the European Social Fund (ESF) (its budget being of $€ 80$ billion for the period 2014-2020) (European Social Fund, n.d.).

$\mathrm{SE}$ is a complex and diverse phenomenon, considering its three levels of manifestation, i.e. macro - through processes and policies on societal change (social innovation), meso - the operational mechanisms of organizations that have a social purpose (social enterprises) and micro - given by individual actions of social entrepreneurs (Douglas, Rogers, \& Lorenzetto, 2014).

\section{Steps forward towards the development of social entrepreneurship in Romania}

By referring to the Social Scoreboard indicators (European Commission, 2017), an undesirable reality is Romania's inclusion in the "critical situation" category (indicators are much worse than average, and either not improving sufficiently fast or deteriorating further) for four of the five indicators of the large domain "equal opportunities and access to labor market", respectively three of the four area indicators "public support / social protection and exclusion" (European Commission, 2018, p. 19). (See Table 1)

Table 1 Romania's position according to the Social Scoreboard

\begin{tabular}{|c|c|c|c|}
\hline \multicolumn{2}{|c|}{ Several indicators of Social Scoreboard } & Year & Romania's Position* \\
\hline \multirow{5}{*}{$\begin{array}{l}\text { Equal } \\
\text { opportunities and } \\
\text { access to the } \\
\text { labour market }\end{array}$} & Early leavers from education and training & 2016 & Critical situations \\
\hline & Gender employment gap & 2016 & Critical situations \\
\hline & Income quintile ratio & 2016 & Weak but improving \\
\hline & At risk of poverty or social exclusion rate & 2016 & Critical situations \\
\hline & Youth NEET rate & 2016 & Critical situations \\
\hline \multirow{4}{*}{$\begin{array}{l}\text { Public support / } \\
\text { Social protection } \\
\text { and inclusion }\end{array}$} & Impact of social transfers on poverty reduction & 2016 & Critical situations \\
\hline & Children aged less than 3 years in formal childcare & 2015 & Weak but improving \\
\hline & Self-reported unmet need for medical care & 2015 & Critical situations \\
\hline & Individuals' level of digital skills & 2017 & Critical situations \\
\hline
\end{tabular}

* EU member states are ranked in 7 large categories, depending on the value of the indicators. These categories are: Best performers, Better than average, On average, Good but to monitor, Weak but improving, To watch, Critical situations.

Source: adapted after (European Commission, 2018, p. 19) 
Issue no. $27 / 2018$

The situation is not surprising given that $38.8 \%$ of the total population was at risk of poverty or social exclusion (in 2016 compared to $37.4 \%$ in 2015, the EU-28 average being $23.5 \%$ in 2015), respectively $45.6 \%$ of the total young population (18-24) was at risk of poverty or social exclusion (in 2016 compared to $45.5 \%$ in 2015, with the EU-28 average at $31.3 \%$ in 2015) (European Commission, Directorate-General for Employment, Social Affairs and Inclusion, 2017, pg. 416-417). However, in Romania "spending on social protection as a \% of GDP is among the lowest in the EU, so it is the effectiveness of social transfers, mainly because social transfers are not adjusted to the economic context" (Reianu, 2016, p. 97).

The involvement of civil society in social entrepreneurship in Romania, which has become more visible since 2011 as a result of several projects financed from European funds (Mateescu, 2014, p. 56) is still considerable, taking into account the projects carried out by the Civil Society Development Foundation (CSDF), NESsT Romania Foundation, Ashoka Romania etc. Other forms of supporting social entrepreneurship in Romania are innovation spaces and competitions (Ashoka Romania, 2018, p. 47). The Institute of Social Economy (ISE), launched and developed by the CSDF in 2011 under the project "PROMETEUS - Promoting Social Economy in Romania through Research, Education and Vocational Training at European Standards", co-financed by the ESF through the Sectorial Operational Program Human Resources Development 2007-2013 (SOP HRD) (Institutul de Economie Socială_a) is an active supporter and promoter of SE in Romania. This institute published the Social Economy Atlas, the 2011, 2012 and 2014 editions (Institutul de Economie Socială_b), an extremely relevant source, and as a result, quoted in all studies related to the situation of this sector in Romania. ISE is involved and has good policy results on the Romanian social economy, with a major interest in the legal framework dedicated to this sector. The adopted form of the Social Economy Law (Parlamentul României, 2015) resulted from ample debates on its content, the amendments made by the Coalition for Social Economy being debated within the standing committees of the Senate and the Chamber of Deputies for over a year and a half (Institutul de Economie Socială_c). Moreover, ISE, through the Coalition for Social Economy, was actively involved in the rejection of the Social Entrepreneurship Law project (within which SE was defined as completely different from any established and recognized definition, being identified with the social responsibility of the companies), the law being passed in the Senate in May 2011, although having a negative 
Issue no. $27 / 2018$

opinion of the Legislative Council, respectively 3 negative opinions from three important committees of the Chamber of Deputies (Institutul de Economie Socială_d). This effort led to the intended aim, the draft of this law being rejected in 2014 (Institutul de Economie Socială, 2014).

The promulgation of the Social Economy Law (Parlamentul României, 2015) in 2015 is a first step in defining the legislative framework dedicated to this sector. At the time of its promulgation there were already existing organizations with an important tradition, such as Mutual Benefit Houses (with 1.5 million elderly people and almost 1 million workers), several social active NGOs concerned with the integration of vulnerable groups in the labor market, in social inclusion enterprises (Institutul de Economie Socială, 2015). The Law on Social Economy specifies the legal entities that may fall under the category of social enterprises (Article 3), namely: cooperative enterprises, credit unions, associations and foundations, mutual companies of employees and pensioners, other categories of legal entities that comply with the provisions of the law, and the federations and unions of the legal entities listed above (Parlamentul României, 2015, pp. 1-2). The certification of the existence of a social enterprise requires obtaining a document, provided that four criteria are fulfilled cumulatively (see Article 8): the aim pursued (which must be social and/ or in the general interest of the community), the allocation of profits achieved (at least $90 \%$ of which will be allocated for the social purpose and statutory reserve), the way of submitting the assets left after winding-up (which will be made to one or more social enterprises) and the application of the social equity principle towards the employees (regarding the salary levels, between which there can be no differences that exceed the ratio of 1 to 8 ) (Parlamentul României, 2015, pp. 3-4). The effects of this law can be seen, even if at a lower rate than desired, in 103 certified social enterprises, in 34 counties being registered in the Single Register of Social Enterprises in May 2018, 48 of them being attested in 2016, 51 in 2017, and 4 in the first 4 months of 2018 (Ministerul Muncii și Justiției Sociale; AJOFM Constanța, 2018). As a result, the statistics on social enterprises in Romania need to be completed with the certified entities, which denotes a development of this sector, even if at first sight at organizational form level. Another positive aspect regarding the legal framework of SE in Romania is the existence in the Classification of Occupations in Romania of three professional occupations in the field of social economy, namely Social Economy Entrepreneur - code 112032 (Ministrul muncii, familiei şi protecţiei sociale; Institutului Naţional de Statistică, 8.08.2011), Social Enterprise Manager - 
code 112036 and Social Economy Specialist - code 341206 (Ministrul muncii, familiei şi protecţiei sociale; Institutului Naţional de Statistică, 22.02.2018). The current situation is positive, if we relate to the situation from 4 years ago, when "a major challenge perceived by stakeholders is the lack of a clear legal and regulatory framework for social enterprises" (Etchart, Iancu, Rosandić, Mocanu, \& Paclea, 2014, p. 6). However, the social economy sector is evolving and, as a consequence, the needs of social entrepreneurs evolve as well. As a result, they mention the lack of a favorable legislative framework (mentioned by $31 \%$ of the study participants), the aspects mentioned being the improvement of the fiscal framework, the definition of terms and the decrease of bureaucracy (Ashoka Romania, 2018, p. 32).

The ESF has had a significant impact on the development of social enterprises in Romania, generous grants motivating many non-profit organizations to develop social economy projects and create - not develop - social enterprises (Damaschin-Țecu \& Etchart, 2016, p. 5). "The almost EUR 300 mil. allocation for the social economy field - within a specific key area of intervention (KAI) - through the SOP HRD constitutes a proof of the importance the Romanian authorities understand to give to this field and of the capitalization of the opportunities to convert social disadvantages into modes of sustainable living" (Matei \& Dorobantu, 2015, p. 491). SOP HRD 2007 is continued by the Operational Programme Human Capital 2014-2020 (OP HC 20142020). A first series of project calls dedicated to the social economy under OP HC 2014-2020 is "Solidar - Support for Social Economy Consolidation", launched in September 2016 with a budget of $€ 20$ million (with EU co-financing of $€ 17$ million, the rest being national cofinancing). Certified social enterprises are targeted, which are competing to obtain funds with a minimum value of $€ 40.000$ and $€ 100.000$, the aid granted to a single enterprise reaching a maximum cumulative value of $€ 200.000$ over three financial years (Programul Operaţional Capital Uman, 2016, p. 11). The result of this call was not the desired one, with only 57 projects submitted, out of which 51 were rejected (POCU: Din cele 57 e proiecte depuse pe apelul Solidar, 51 au fost respinse, 2017). In august 2018, the call for projects "Support for the establishment of social enterprises" is launched (AP 4/PI 9.v/OS 4.15) - Solidar Start-up, with an available budget of $€ 70$ million, that targets the selection of scheme administrators for social economy entities, which in turn will support through activities and non-refundable financing the establishment, development and monitoring of social enterprises (Programul Operaţional Capital 
Issue no. $27 / 2018$

Uman, 2018, pp. 6, 17). The allocated funds are significant, but the way the funding is structured leads strictly to the establishment of social enterprises, lacking the growth and sustainability phase of the business model (Damaschin-T,ecu \& Etchart, 2016, p. 5). The NESsT foundation responds to this challenge for social entrepreneurs in Romania by "educating" those involved in Romanian social economy structures about the existence of mixed financial instruments that are actively used in more advanced markets, but still slowly adopted in countries from Central and Eastern Europe (Damaschin-Țecu \& Etchart, 2016, p. 14). This foundation has been organizing (or has been a partner in) competitions for social affairs, providing financial support, consultancy and training) since 2011, when there was a need for a mental change at NGO level towards a market oriented approach, attentive to competition, from an approach centered on the donor/ financier, respectively there was a lack of knowledge and business skills, at the level of those willing to engage in social affairs (Damaschin-Țecu, 2010). Over time, this competition has grown to the level of the budget allocated to winning social businesses, attracting important partners, such as Romanian-American Foundations, CitiRomania (Ispas, 2013) or co-financiers, such as Swiss-Romania Cooperation Programme, UniCredit Foundation and "Alături de Voi" (ADV), Iași (NESsT, 2015). NESsT Foundation invested more than \$ 1 million in Romania, in order to strengthen the capacity and to directly finance 21 social enterprises that are part of its portfolio during the period 2011-2016 (Damaschin-T,ecu \& Etchart, 2016, p. 6). We note the involvement of NESsT as a partner in the two editions of the Social business competition called "Made in Andrei's Country", carried out by OMV Petrom in the period 2013-2017, where the 20 winner social businesses (which created 60 jobs) received funding of over $€ 700.000$ (T, Tara lui andrei, n. d.; NESst, n.d.). The access to finance is the main challenge identified by social entrepreneurs in Romania, the situation in recent years being unchanged from this point of view (Etchart, Iancu, Rosandić, Mocanu, \& Paclea, 2014; Damaschin-T,ecu \& Etchart, 2016; Ashoka Romania, 2018). However, it is necessary to refine the idea; the sources of financing, especially those from European funds, through their structure, are meant for the establishment of social enterprises and do not address the other stages of enterprise development - validation, preparation for extension, extension (Damaschin-T,ecu \& Etchart, 2016, p. 15). As a result, the phrase "access to finance as a challenge" refers to a capital market for social enterprises that are only in start-up phase. Thus, BCR Romania has carried out a pilot program for the financing of social enterprises, 
Issue no. $27 / 2018$

which offers credits at zero cost and no guarantees for the development of social affairs (Știri ONG, 2011). At present, BCR Romania, as a member of Erste Group, funds social organizations under the guise of the European Program for Employment and Social Innovation (EaSI), following the agreement signed by the European Investment Fund (Ciutacu, 2018). Another entity that provides bridge loans is the Romanian-American Foundation (FRA), which collaborates with NESsT (Damaschin-Țecu \& Etchart, 2016, p. 40). These positive examples, from the perspective of capital supply for social enterprises, are complemented by examples from demand perspective, namely cases of social enterprises that use financial instruments dedicated for them. One such example is Alături de Voi (ADV) Foundation, which needed a bridge loan in order to cope with the reimbursement mechanism of a European funded project and, as a result, the foundation got a loan from a Polish institution which grants loans to social enterprises under customized conditions - an acceptable interest rate and a reimbursement schedule according to the ongoing project cycle, in this process NESsT being the one who negotiated with the Polish institution and provided a guarantee for the loan (Damaschin-Țecu \& Etchart, 2016, p. 29). In the view of the above, another challenge identified by the SE stakeholders, namely the "difficult access to finance; SEs are ignored or discriminated by mainstream financiers, such as banks" (Etchart, Iancu, Rosandić, Mocanu, \& Paclea, 2014) has been overcome, at least to a certain extent. And yet, according to a study carried out by the Ashoka global organization, which was attended by 40 social Romanian entrepreneurs (data gathered in April-May 2017), the access to finance is mentioned as the greatest challenge (aspect mentioned by 22 of the 40 social entrepreneurs participating at the study), whether it is public financing, considered low, nonstrategic and uninterrupted, or private financing, often seen as uncertain, with possible changes in the interest of the financiers (Ashoka Romania, 2018, p. 29).

Regarding the involvement of private companies in SE, the concept of Corporate Social Responsibility (CSR) has evolved over the past ten years, and more advanced companies are beginning to believe that philanthropy and CSR activities are somewhat overrated and focused more on marketing than on a sustainable social impact (Damaschin-Țecu \& Etchart, 2016, p. 13). According to this study, companies are increasingly embracing the concept of "social investment", starting to look at how they can incorporate social and environmental impacts into their core business and investment. We note that Romania CSR Index follows the social, 
Issue no. $27 / 2018$

economic and environmental themes, with the Community Investment Category indicator assessing the company's social impact, although only 14\% of the 100 companies participating in the study have provided details in this respect (The Azores Sustainability; CSR Services, 2017).

The development of social entrepreneurship education has as a starting point a number of projects, carried out or in progress, financed from European funds or by private companies, aimed at developing this field (at both curricula and ecosystem level). We mention the Social Enterprise 360 Project that was developed with the help of a strategic partnership with participants from 8 countries (target groups being teachers and high school directors, high school students, entrepreneurs, experts, media, public and private networks supporting entrepreneurship education in schools), co-funded through the Erasmus + program, which took place in the period 2014-2016 (Social Enterprise 360, n.d.). Among the objectives of this project, we note the following: the creation of a social entrepreneurship curriculum for high school, respectively the creation of an ecosystem for social entrepreneurship inside and outside school, and the exploitation of learning, objectives leading to a favorable framework for a SE education, at the level of high school students. The project Social Innovation Relay (SIR) is also addressed to high school students, and it consists of organizing a competition of innovative business concepts based on social needs or issued, the project being developed at the level of several countries, being carried out in partnership with the NN Group (JA Romania, n.d.). For example, 3300 students and 109 teachers from 131 high schools in Romania participated at the 2018 edition, the competition being between 125 of them, and the 20 winning teams beneficiated of free mentoring and consultancy from $11 \mathrm{NN}$ volunteers, to propose and develop entrepreneurial and social innovation projects (JA Romania, 2018). These projects that aim at educating young people on social entrepreneurship in the context of a good perception of SE in Romania, "social enterprises are seen by the general public and key stakeholders (government, non-profits, social entrepreneurs) as a way to promote economic and social inclusion" (Etchart, Iancu, Rosandić, Mocanu, \& Paclea, 2014, p. 1) lead to a positive overall framework for the development of SE.

Other challenges that social entrepreneurs have to deal with are: the lack of know-how resulting in a lack of experience in social impact measurement, long-term strategies or entrepreneurial and fundraising skills, and collaboration at system level, not just on projects (Ashoka Romania, 2018, p. 36); access to markets (they are small and fragmented, with limited 
Issue no. $27 / 2018$

marketing capabilities), access to adequately trained employees, a risk-tolerant environment with limited tolerance to failure, which makes the social enterprise bear and manage on its own the excessive costs of innovation, as well as those related to generating and piloting new ideas or products (Damaschin-Țecu \& Etchart, 2016, p. 12). The multitude of challenges is due both to the complexity of the SE domain and to the current situation in Romania, both in terms of social needs and in the context of the elements that influence the process of those interested in activating in the social economy.

\section{Conclusion}

SE challenges can be traced from at least two perspectives, one of the entrepreneur (as an individual) - focusing on motivation, qualities, knowledge, training, etc., and the other is the process of becoming an entrepreneur, which is strongly conditioned by formal and informal institutions. The present study adopts the second perspective, our interest being to identify the SE challenges that are given by the environmental factors and the components of the ecosystem of the social economy, in the general context given by the institutional approach of SE.

A first conclusion is that with respect to the social ecosystem of the social enterprises in Romania, there is a positive evolution, if we relate to the situation in 2014 when there was a poor recognition of the concept of social enterprise, there was no policy framework to support or encourage the creation and development of social enterprises, the access to financial resources and tax incentives was limited, the associations and foundations carrying out economic activities were treated in the same way as commercial ones in terms of administrative burdens and tax regimes (European Commission, 2014, p. 6).

A second conclusion of the present study is that the major role played by civil society in the development of SE in Romania is still considerable, given the projects developed by the Civil Society Development Foundation (CSDF), NESsT Romania Foundation, Ashoka Romania, etc. These organizations are active in several strategic directions, such as analyzing the social economy sector by producing and publishing the Social Economy Atlas (Barna, 2014); the involvement in the formulation of SE policies, including the great effort of the Institute of Social Economy, through the Coalition for Social Economy for a specific legislative framework in this sector and in line with internationally recognized approaches; providing financing by organizing 
competitions addressed to social economy structures, doubled by consultancy and training; providing "financial education" both to the beneficiaries of a capital market for social enterprises in the training phase and to the bidders - who have to adopt financial instruments adapted to the specifics of this sector. The involvement of the business environment in the development of SE in Romania is ongoing, the situation being a positive one, as the CSR activities are complemented by the so-called "social investment", which involves analyzing how companies can incorporate social and environmental impacts into their core business and investment. This trend is also identified by finding the company's social impact assessment indicator in the Community Investments Category from the Romania CSR Index (The Azores Sustainability; CSR Services, 2017).

The SE specific legislation in Romania has an important role in the process of becoming a social entrepreneur. Therefore, another conclusion of this study is that the current situation with regard to SE specific legislation is good, if we relate to the situation from 4 years ago when "a major challenge perceived by stakeholders is the lack of a clear legal and regulatory framework for social enterprises" (Etchart, Iancu, Rosandić, Mocanu, \& Paclea, 2014, p. 6).

The following conclusion concerns the access to finance, identified as the main challenge by social entrepreneurs in Romania (Etchart, Iancu, Rosandić, Mocanu, \& Paclea, 2014; Damaschin-T,ecu \& Etchart, 2016; Ashoka Romania, 2018). So, we conclude that the phrase "access to financing as a challenge" refers to a capital market for social enterprises in the start-up phase; the financial instruments dedicated to the social economy sector, such as bridge loans, are in an "early" stage in Romania. The argument is that European funds, which predominate in the financing of social enterprises, through their funding structure, are used only to establish the structures of the social economy, and the following phases of development and sustainability are not taken into account.

A final conclusion of this research is that, once these challenges of SE in Romania are identified, it is necessary to carry out further studies leading to a series of possible solutions, considering the increase of the interest for this field in our country, respectively the development of the social economy sector. 
Issue no. $27 / 2018$

\section{References}

- ABU-SAIFAN, S. (2012). Social Entrepreneurship: Definition and Boundaries. Technology Innovation Management Review, 22-27.

- ASHOKA ROMANIA. (2018, March 28). Raportul Național despre Antreprenoriatul Social in România. (in Romanian) http://ashokacee.org/romania/2018/03/28/ecosistemul-antreprenoriatului-social-in-romania/, (Retrieved on: June 30, 2018).

- AUSTIN, J., STEVEnSON, H., \& WEI-SKILlERN, J. (2006). Social and Commercial Entrepreneurship: Same, Different, or Both? Entrepreneurship Theory and Practice, Vol. 30, Issue 1, 1-22.

- BARNA, C. (2014). Atlasul Economiei Sociale, România 2014. București: Institutul pentru Economie Socială (in Romanian).

- BIBU, N., LISETCHI, M., \& NASTASE, M. (2016). Management particularities of the Romanian Social Enterprise. In O. NICOLESCU, \& L. LLOYD-REASON, Challenges, Performances and Tendencies in Organization Management (pp. 243259). New Jersey: World Scientific.

- BOetTKE, P. J., \& COYNE, C. J. (2009). Context Matters: Institutions and Entrepreneurship. Foundations and Trends $R{ }^{\circledR}$ in Entrepreneurship, Vol. 5, No. 3, 135-209.

- BOSMA, N. S., SCHØTT, T., TERJESEN, S. A., \& KEW, P. (2016). Global Entrepreneurship Monitor 2015 to 2016: Special Report on Social Entrepreneurship.

- BYLUND, P. L., \& MCCAFFREY, M. (2017). A theory of entrepreneurship and institutional uncertainty. Journal of Business Venturing, 32, 461-475.

- CACE, C., CACE, S., COJOCARU, Ș., \& SFETCU, L. (2013). Social economy in Romania - challenges and perspectives. Transylvanian Review of Administrative Sciences, No. 40 E, 5-21.

- CIRIEC, Centre of Research and Information on the Public. (2012). The Social Economy in the European Union. https://www.eesc.europa.eu/resources/docs/qe-3012-790-en-c.pdf, (Retrieved on: June 22, 2018). 
Issue no. $27 / 2018$

- CIUTACU, A. (2018, June 19). Fondul European de Investiţii şi Erste Group au semnat un acord de 50 de milioane de euro pentru finanţarea companiilor sociale şi a organizaţiilor non-profit din România, Austria, Croaţia, Cehia, Ungaria, Slovacia şi Serbia. Ziarul Financiar (in Romanian).

- DACIN, T. M., DACIN, A. P., \& TRACEY, P. (2011). Social Entrepreneurship: A Critique and Future Directions. Organization Science, Vol. 22, No. 5, 1203-2013.

- DACIN, P. A., DACIN, T. M., \& MATEAR, M. (2010). Social Entrepreneurship: Why We Don't Need a New Theory and How We Move Forward From Here. Academy of Management Perspectives, 24 (3), 37-57.

- DAMASCHIN-ȚECU, R. (2010, December 10). Interviu NESsT: Modele de intreprinderi sociale in Romania. (in Romanian). http://www.romaniapozitiva.ro/featured/interviu-nesst-modele-de-intreprinderisociale-in-romania/, (Retrieved on: June 24, 2018).

- DAMASCHIN-ȚECU, R., \& ETCHART, N. (2016). Cazul României Dezvoltând industria investițiilor sociale în Europa Centrală și de Est. NESst. (in Romanian).

- DEES, G., \& BATTLE ANDERSON, B. (2006). Framing a Theory of Social Entrepreneurship. Building on Two Schools of Practice and Though. In R. MOSHERWILLIAMS (editor), Research on Social Entrepreneurship: Understanding and Contributing to an Emerging Field.

- DÍAZ CASERO, J. C., ALMODÓVAR GONZÁlEZ, M., SÁNCHEZ ESCOBEDO, M. D., CODURAS MARTÍNEZ, A., \& HERNÁNDEZ MOGOLLÓN, R. (2013). Institutional variables, entrepreneurial activity and economic development. Management Decision, Vol. 51 Issue: 2, 281-305.

- DORADO, S., \& VENTRESCA, M. J. (2013). Crescive entrepreneurship in complex social problems: Institutional conditions for entrepreneurial engagement. Journal of Business Venturing, 28, 69-82.

- DOUGLAS, H. (2010). Divergent orientations of social entrepreneurship organisations. În K. HOCKERTS, J. MAIR, \& J. ROBINSON, Values and opportunities in social entrepreneurship (pg. 71-95). UK: Palgrave, UK. 
- DOUGlas, H., ROGERS, J., \& LORENZETTO, A. (2014). Design thinking and social enterprise innovation. In A. Hermens (editor), Proceedings of the 28th Australia and New Zealand Academy of Management Conference, ANZAM (pg. 1-15). Sydney, Australia.

- DUMA, F. (2014). Promoting the entrepreneurship education in Europe. On-line Journal Modelling the New Europe, Issue no.10, 67-79.

- ESELA- European Social Enterprise Law Association. (2015). Social Enterprise in Europe Developing Legal Systems which Support Social Enterprise Growth.

- $\quad$ ETCHART, N., IANCU, D., ROSANDIĆ, A., MOCANU, V., \& PACLEA, I. (2014). The State of Social Entrepreneurship in Romania SEFORÏS Country Report.

- European Commission. (2014). A map of social-enterprises and their eco-systems in Europe, Country Report: Romania.

- European Commission. (2017). Social Scoreboard 2017, Headline indicators: descriptions and highlights.

- European Commission. (2018). Joint Employment Report 2018: As Adopted by the EPSCO Council on 15th March 2018. Bruxelles.

- European Commission, Directorate-General for Employment, Social Affairs and Inclusion. (2013). Social economy and social entrepreneurship, Social Europe guide | Volume 4.

- European Commission, Directorate-General for Employment, Social Affairs and Inclusion. (2017). Social Protection Committee Annual Review 2017.

- European Economic and Social Committee. (2017). Recent Evolutions of the Social Economy in the European Union. https://www.eesc.europa.eu/sites/default/files/files/qe-04-17-875-en-n.pdf, (Retrieved on: June 24, 2018).

- European Social Fund. (n. d). http://ec.europa.eu/social: http://ec.europa.eu/social/main.jsp?catId=325\&langId=en, (Retrieved on: June 24, 2018).

- FERRI, E., \& URBANO, D. (2010). Environmental Factors and Social 
Issue no. $27 / 2018$

Entrepreneurship. Working Papers 1003, Departament Empresa, Universitat Autònoma de Barcelona.

- GÜMÜSAY, A. A. (2018). Unpacking entrepreneurial opportunities: an institutional logics perspective. Innovation: Organization \& Management, Volume 20, Issue 3, 209-222.

- HADAD, S., \& GĂUCĂ (DRUMEA), O. (2014). Social impact measurement in social entrepreneurial organizations. Management \& Marketing. Challenges for the Knowledge Society, Vol. 9, No. 2, 119-136.

- HOOGENDOORN, B. (2016). The Prevalence and Determinants of Social Entrepreneurship at the Macro Level. Journal of Small Business Management, 54(S1), 278-296.

- HUYBRECHTS, B., \& NICHOLLS, A. (2012). Social Entrepreneurship: Definitions, Drivers and Challenges. In C. K. VOLKMANN, K. O. TOKARSKI, \& K. ERNST (editors), Social Entrepreneurship and Social Business. An Introduction and Discussions (pp. 31-48). Gabler Verlag.

- Institutul de Economie Socială. (2014, April 24). Legea Antreprenorului social reloaded. (in Romanian). http://www.ies.org.ro/info-stiri/vrs/IDstire/947/t/legeaantreprenorului-social-reloaded, (Retrieved on: June 22, 2018).

- Institutul de Economie Socială. (2015, July 22). Presedintele Iohannis a promulgat astazi Legea economiei sociale. (in Romanian). http://www.ies.org.ro/infostiri/vrs/IDstire/1106/t/dupa-ani-de-dezbateri-legea-economiei-s, (Retrieved on: June 30, 2018).

- Institutul de Economie Socială_a. (n. d.). Ce este Institutul de Economie Socială? (in Romanian). http://www.ies.org.ro/ies-1, (Retrieved on: June 23, 2018).

- Institutul de Economie Socială_b. (n. d). Atlasul de Economie Socială. (in Romanian). http://www.ies.org.ro/atlasul-economiei-sociale, (Retrieved on: June 23, 2018).

- Institutul de Economie Socială_c. (n. d.). Coaliția pentru Economia Socială. (in Romanian). http://www.ies.org.ro/politici/coalitia-pentru-economie-sociala, (Retrieved on: June 23, 2018). 
- Institutul de Economie Socială_d. (n. d.). Reacția față de Legea antreprenorului sociale. (in Romanian). http://www.ies.org.ro/politici/demersuri-ies-fdsc/legeaantreprenorului-social-pl-x-361-1/demers, (Retrieved on: June 23, 2018).

- ISENBERG, D. J. (2010). How to start an entrepreneurial revolution. Harvard Business Review, 2010, 88(6), 40-50.

- ISPAS, M. (2013, June 9). S-a lansat Competiția NESsT pentru Intreprinderi Sociale 2013. (in Romanian) http://revistacariere.ro/uncategorized/actual/s-a-lansatcompetitia-nesst-pentru-intreprinderi-sociale-2013, (Retrieved on: June 25, 2018).

- JA Romania. (2018, May 10). Liceeni participanți la competiția Social Innovation Relay, viitori antreprenori sociali. (in Romanian). http://sir.jaromania.org/media/liceenii-participanti-la-competitia-social-innovationrelay-viitori-antreprenori-sociali, (Retrieved on: June 30, 2018).

- JA Romania. (n.d.). Despre proiect. (in Romanian) http://sir.jaromania.org/despreproiect, (Retrieved on: June 30, 2018).

- MAIR, J., \& MARTÍ, I. (2006). Social entrepreneurship research: a source of explanation, prediction, and delight. Journal of World Business, 41, 36-44.

- MATEESCU, V. M. (2014). Perspectives on Social Entrepreneurship in Romania. On-line Journal Modelling the New Europe, Issue no. 10, 55-66.

- $\quad$ MATEI, A., \& DOROBANTU, A. D. (2015). Social economy - added value for local development and social cohesion. Procedia Economics and Finance, Volume 26, 490 $-494$.

- MEEK, W. R., PACHECO, D. F., \& YORK, J. G. (2010). The impact of social norms on entrepreneurial action: Evidence from the environmental entrepreneurship context. Journal of Business Venturing, 25, 493-509.

- Ministerul Muncii și Justiției Sociale; AJOFM Constanța. (2018, May). Informare privind intreprinderile sociale atestate. (in Romanian). http://www.constanta.anofm.ro: http://www.constanta.anofm.ro/pages/economiesociala/Informare\%20economie $\% 20 \mathrm{~s}$ ociala_mai2018.pdf, (Retrieved on: June 30, 2018). 
Issue no. $27 / 2018$

- Ministrul muncii, familiei şi protecţiei sociale; Institutului Naţional de Statistică. (22.02.2018). ORDIN nr. 177 din 7 februarie 2012 privind modificarea şi completarea Clasificării ocupațiilor din România - nivel de ocupaţie (şase caractere). Monitorul Oficial 128. (in Romanian).

- Ministrul muncii, familiei şi protecţiei sociale; Institutului Naţional de Statistică. (8.08.2011). ORDIN Nr. 1832/856 din 6 iulie 2011 privind aprobarea Clasificării ocupaţiilor din România - nivel de ocupaţie (şase caractere). Monitorul Oficial, Nr. 561. (in Romanian).

- NESsT. (2015, February 9). Competitia NESsT pentru Intreprinderi Sociale 2015. (in Romanian), http://www.romaniapozitiva.ro/romania-internationala/competitia-nesstpentru-intreprinderi-sociale-2015/, (Retrieved on: June 30, 2018).

- NESsT (n.d.). Made in Andrei's country. https://www.nesst.org/made-in-andreiscountry, (Retrieved on: June 28, 2018).

- PACHE, A. C., \& CHOWDHURY, I. (2012). Social Entrepreneurs as Institutionally Embedded Entrepreneurs: Toward a New Model of Social Entrepreneurship Education. Academy of Management Learning \& Education, Vol. 11, No. 3, 494-510.

- Parlamentul României. (2015, July 28). Lege Nr. 219 din 23 iulie 2015 privind economia socială. Monitorul Oficial NR. 561. (in Romanian).

- POCU: Din cele 57 de proiecte depuse pe apelul Solidar, 51 au fost respinse. (2017, April 28). (in Romanian). https://www.fonduri-structurale.ro/stiri/18471/pocu-dincele-57-de-proiecte-depuse-pe-apelul-solidar-51-au-fost-respinse, (Retrieved on: June 30, 2018).

- Programul Operațional Capital Uman. (2016). Ghidul Solicitantului - Condiții specifice. Solidar - Sprijin pentru consolidarea economiei sociale. Schemă de ajutor de minimis. Dezvoltare întreprinderi de economie socială. (in Romanian).

- Programul Operațional Capital Uman. (2018). Ghidul solicitantului - condiții specifice. Sprijin pentru înființarea de intreprinderi sociale (AP 4/PI 9.v/OS 4.16). (in Romanian).

- RACOLȚA-PAINA, N. D., \& BURCĂ-VOICU, M. I. (2013). The Competitiveness 
Issue no. $27 / 2018$

of SMEs in the EU Member States. Challenges and Lessons Ahead for Romania. Studia Universitatis Babeș-Bolyai, Studia Europaea, Year L VIII, nr. 3, 37-60.

- RACOLȚA-PAINA, N. D. (2016). The European Single Market: Opportunities for Entrepreneurs. The case of Erasmus for Young Entrepreneurs. Studia Universitatis Babeș-Bolyai, Studia Europaea, Issue no. 4, 21-41.

- REIANU, D. G. (2015). Mainstreming the gender dimension in the Europe 2020 Strategy. Studia Universitatis Babeș-Bolyai, Studia Europaea, Year L X, nr. 4, 5-18.

- REIANU, D. G. (2016). Policy responses to poverty: Is Romania on the road towards a new integrative approach? On-line Journal Modelling the New Europe, nr. 20, 91108.

- RICHTER, R. (2005). The New Institutional Economics: Its Start, Its Meaning, Its Prospects. European Business Organization Law Review (EBOR), 6(2), 161-200.

- ROUNDY, P. T. (2017). Social entrepreneurship and entrepreneurial ecosystems: complementary or disjointed phenomena? International Journal of Social Economics, 44(9), 1-18.

- SALAMON, L., \& SOKOLOWSKI, W. (2014). The third sector in Europe: Towards a consensus conceptualization, TSI Working Paper Serie, No. 2. European Union, Brussels.

- SCHMIDT, H. J., \& CARSTEN, B. (2014). Introducing a conceptual model of brand orientation within the context of Social Entrepreneurial Businesses. International Journal on Strategic Innovative Marketing, Volume 01, Issue 01, 37-50.

- SILVA, A. C., \& POZA, C. (2016). A Review of the Social Entrepreneurship Phenomenon. In J. M. SAIZ-ÁLVAREZ, Handbook of Research on Social Entrepreneurship and Solidarity Economics (pg. 1-26). USA: IGI Global.

- Social Enterprise 360. (n.d.). Proiect. (in Romanian). http://socialenterprise360.org/despre-proiect/proiect, (Retrieved on: June 30, 2018).

- SPIEGEL, B. (2015). The Relational Organization of Entrepreneurial Ecosystems. Entrepreneurship Theory and Practice, 41(1), 49-72.

- STENHOLM, P., ACS, Z. J., \& WUEBKER, R. (2013). Exploring country-level 
institutional arrangements on the rate and type of entrepreneurial activity. Journal of Business Venturing, 28, 176-193.

- Știri ONG. (2011, September 07). Credite pentru intreprinderi sociale de la BCR. (in Romanian). https://www.stiri.ong/finantari-si-csr/articol/credite-pentru-intreprinderisociale-de, (Retrieved on: June 30, 2018).

- The Azores Sustainability; CSR Services. (2017). ROMANIA CSR INDEX 2017. (in Romanian) https://www.theazores.ro/wpcontent/uploads/2017/09/Romania_CSR_Index_2017_Detailed_Report-1.pdf, (Retrieved on: June 23, 2018).

- $\quad$ TOLBERT, P. S., DAVID, R. J., \& SINE, W. D. (2010). Studying choice and change: The intersection of institutional theory and entrepreneurship research. Organization Science, 22 (5), 1332-1344.

- Țara lui Andrei (n. d.), Puterea afacerilor sociale. (in Romanian). https://www.taraluiandrei.ro/fabricat-in-tla\#/2015-2017, (Retrieved on: June 30, 2018).

- URBANO, D., TOLEDANO, N., \& SORIANO, D. R. (2010). Analyzing Social Entrepreneurship from an Institutional Perspective: Evidence from Spain. Journal of Social Entrepreneurship, Vol. 1, No. 1, 54-69.

- VECIANA, J. M., \& URBANO, D. (2008). The institutional approach to entrepreneurship research. Introduction. International Entrepreneurship and Management Journal, Volume 4, Issue 4, 365-379.

- WITKAMP, M. J., ROYAKKERS, L. M., \& RAVEN, R. P. (2011). From Cowboys to Diplomats: Challenges for Social Entrepreneurship in The Netherlands. Voluntas, $22,283-310$.

- ZOEHRER, K. (2017). Social entrepreneurship in southeastern Europe - Comparative analysis of the cases of Croatia, Serbia and Greece. Social enterprise for sustainable societies LLN, ECSP-6EMES-02, 1-39. 